МИХЕЕВ Валентин Александрович - доктор исторических наук, академик РАЕН; профессор Российской академии народного хозяйства и государственной службы при Президенте РФ (119571, Россия, г. Москва, пр-кт Вернадского, 82; mikheеvva37@таil.ru)

\title{
ГРАЖДАНИН И ПРАВЯЩИЙ КЛАСС: ПУТИ ВЗАИМОДЕЙСТВИЯ В СОВРЕМЕННОЙ РОССИИ
}

Аннотация. В статье анализируются вопросы теории, способы, методы взаимодействия граждан и правящего класса в контексте формирования системы публичной власти.

Ключевые слова: гражданин, правящий класс, публичная власть, коррупция, конкуренция, доверие

$\mathrm{B}$ постнеклассической науке гражданин характеризуется как человек, имеющий гражданство определенного государства, в своей действительности выражающий совокупность всех общественных отношений, процессов взаимосвязей с государством и обществом.

Правящий класс современной России - это граждане, представители различных социальных и профессиональных групп, слоев, страт, облеченные властью, выполняющие функции управления в государстве и обществе.

Один из основателей теории правящего класса итальянский экономист, социолог Гаэтано Моска (1854-1941) называет правящий класс «организованным меньшинством, осуществляющим власть и неизменно обладающим свойствами, реальными или кажущимися, которые глубоко почитаются в том обществе, где они живут» [Моска 2006: 54-55]. Правящие классы, подчеркивал он, «приходят в упадок, если перестают совершенствовать привычные для них социальные функции, а их таланты и служба утрачивают в обществе свою значимость» [Моска 2006: 56]. Российский историк и политолог В.О. Ключевский (1841-1911) определял, что «политические классы (прототипы правящего класса - Aвm.) заменятся разрядами или степенями интеллектуального развития, то есть по способности умственного напряжения» [Ключевский 1990: 333]. Ученые, в свою очередь, подчеркивают, что «правящий класс осуществляет власть внутри общества, а не над ним, в теории могут существовать способы управления для народа, но не управление народом» [Арон 1993: 48].

Создание в современной России единой системы публичной власти - задача своевременная и значимая. В политической современности мы обнаружим не много процессов разворота государственной власти к публичности.

В ряде стран отношение к публичной власти противоречивое, а нередко негативное. К примеру, в США значительная власть принадлежит элите, в т.ч. так называемому закрытому не публичному клубу, который занимается подбором кандидатов в президенты, проведением выборов, но доступ в него не гарантирован даже действующим президентам США [Литвак 2011: 165]. Правящий класс в США именуется классом $x$, «бобо» (богема и буржуазия), политико-административным классом и др. [Флорида 2011: 84-85].

В условиях формирования публичной власти в современной России повышается роль, ответственность органов государственного и муниципального управления, усиливается внимание к правящему классу, формированию его инновационных способностей. Взаимодействие гражданина и правящего класса выражает более широкий спектр контрастов в формах, функциях и способах проявлений в сравнении с общепринятым в политической науке тер- 
мином политического участия ${ }^{1}$ и, совершенно очевидно, представляет собой вызов теориям, политико-правовым нормам, экспертным оценкам, сложившимся на современном этапе развития государства и общества.

В самом общем виде взаимодействие гражданина и правящего класса -это воплощение прямых и опосредованных разносторонних личных, общественных связей, характеризующихся специфической определенностью совпадения/несовпадения позиций, интересов, принципов общественной жизни, методов решения актуальных задач, созданием и использованием ресурсов, средств, позволяющих индивидам, социальным, профессиональным слоям, государству и обществу обеспечивать достижение поставленных целей.

Правящий класс современной России, как любой социальный класс, неоднороден. В его состав входят члены правительства РФ, сенаторы, депутаты Государственной думы, высшие должностные лица, депутаты законодательных и представительных собраний субъектов РФ, государственные и муниципальные служащие. Заметим, что в числе лиц правящего класса состояли и состоят многие бывшие работники советской номенклатуры. Российский правящий класс в течение трех десятилетий доказывает свою легитимность, творчески осуществляя государственную власть, обеспечивая управление в интересах народа.

Формирование нового механизма согласованного функционирования и взаимодействия граждан и органов публичной власти осуществляется в условиях слишком сложного переплетения интересов регионов и территорий. По данным Федерального казначейства, большинство регионов (58 из 85 субъектов РФ) завершили 2020 г. с дефицитом бюджета ${ }^{2}$, а в настроениях граждан все чаще выражается необходимость изменения государственной политики. К этому добавляются многослойные трудности пандемии, многолетнее снижение реально располагаемых доходов, высокий уровень бедности населения и т.д.

Нет никаких сомнений, что центр и регионы придут к новой системе публичной власти. Это нужно обеим сторонам. Но перед этим придется перевернуть страницу прежней модели отношений, которая сейчас, увы, вызывает взаимное раздражение в целом ряде направлений.

С некоторых пор существование того, что называется правящим классом, представляется парадоксальным: якобы мы уже порвали с субстанциализмом и ввели реляционистский способ мышления. Анализируя взаимодействие граждан и правящего класса, реальные обмены, прямые контакты, можно констатировать практическую солидарность и практическую изворотливость, практическую законность и практическую коррумпированность, подтверждающиеся в их массовых проявлениях.

К примеру, председатель Следственного комитета РФ. А.И. Бастрыкин отмечает: «За десять лет работы Следственного комитета в суды направлено свыше 90 тысяч уголовных дел о коррупции. <... Перед судом предстали многие высокопоставленные чиновники, губернаторы, министры, руководители департаментов, сотрудники министерств и ведомств, сенаторы, депутаты Государственной Думы, Федерального Собрания Российской Федерации, председатели и судьи районных, городских, областных судов, работники правоохранительных органов власти» ${ }^{3}$.

В обществе коррупция воспринимается не только как технология обогаще-

\footnotetext{
1 Политическое участие понимается как совокупность действий, прямо или опосредованно предпринимаемых индивидами с целью оказания воздействия на государство для осуществления своих требований и решения жизненно важных проблем.

2 Титова А. Денег точно будет меньше: интервью Н. Зубаревич. - Новая газета. 2021. 22 янв.

3 Бастрыкин А.И. Десять лет - не срок. - Российская газета. 2021. 15 янв.
} 
ния правящего класса, но и как процесс ограбления народа, усиления неравенства, обострение противостояния интересов граждан и государства.

Двадцатилетние исследования Левада-Центра (2001-2019 гг.) показали, что от $45 \%$ до $30 \%$ россиян характеризуют нынешнюю власть как коррумпированную, бюрократичную, далекую от народа, чуждую; от $20 \%$ до $15 \%$ - как недальновидную, непоследовательную; и лишь 15\% квалифицируют власть как законную ${ }^{1}$. Почти $3 / 4$ россиян $(72 \%)$ считают, что интересы власти и общества не совпадают ${ }^{2}$.

Многие, даже представители капиталистического класса, указывают на вопиющее тяжелейшее социальное положение населения страны. Один из миллиардеров современной России О. Дерипаска, к примеру, пишет: «...большинство народа бедствует, имеет унизительно низкий доход... менее 27 тысяч рублей в месяц. Стыдно смотреть людям в глаза в регионах... Вопрос их доходов должен обеспечиться быстрым ростом экономики... Но надо честно сказать: программы пока нет. Ни у правительства, ни у административно отвернувшегося от этой проблемы Центрального банка» 3 . По этому поводу один из современных философов К. Поппер отмечает, что «правители и управляемые пойманы в социальную сеть и вынуждены бороться друг с другом» [Поппер 1992: 133].

Правящий класс все более масштабно демонстрирует свою способность изогнуть любую теорию и практику так, чтобы она подходила государственному и общественному управлению, исходя из соображений личной заинтересованности и иных.

Подобных примеров множество - приведу один. В 2014 г. в Ф3 «О профессиональных союзах, их правах и гарантиях деятельности» 4 были внесены изменения (п. 1, ст. 7): «уставы первичных профсоюзных организаций, их объединений (ассоциаций)... не должны противоречить уставам соответствующих профсоюзов, их объединений (ассоциаций)»5. Это вызвало резкую критику граждан и выдвижение требований отменить данную поправку. Заметим, что в различных типах профсоюзов современной России насчитывается около 30 млн чел. (подсчитано автором. - B.M.) ${ }^{6}$, прямо и опосредованно участвующих в процессах взаимосвязей с правящим классом и государством в целом.

По существу, граждане вступили в конкурентное противостояние с правящим классом - с депутатами Государственной думы, лидерами Федерации независимых профсоюзов России - инициаторами внесенных поправок. Запросы граждан по поводу их отмены рассматривались в нескольких государственных, общественных инстанциях, в районных, городских, областных судах и даже в Верховном суде РФ, но безуспешно.

Лишь в ноябре 2020 г. Конституционный суд РФ признал внесенное изменение в Ф3 о профессиональных союзах не соответствующим Конституции

${ }^{1}$ Аптекарь П. Фавлократия по-русски. - Ведомости. 2020. 28 янв.

2 Мухаметшина Е. Общество неинтересно власти. - Ведомости. 2019. 28 нояб.

3 Дерипаска О. Как увеличить ВВП за 12 лет. - Ведомости. 2020. 25 дек.

4 Федеральный закон «О профессиональных союзах, их правах и гарантиях деятельности» от 12.01.1996 № 10-Ф3 (посл. ред.). Доступ: http://www.consultant.ru/document/cons_doc LAW_8840/ (проверено 08.07.2021).

5 Постановление Конституционного Суда РФ по делу «О проверке конституционного пункта 1 статьи 7 Ф3 “О профессиональных союзах, их правах и гарантиях” от 27.10.2020 № 44-П. - Российская газета. 2020. 6 нояб.

6 В Федерации независимых профсоюзов России (ФНПР) и сотрудничающих с ней других профсоюзах на основе договоров насчитывается около 28 млн членов. Кроме того, в так называемых новых профсоюзах, не входящих в состав ФНПР, состоят более 2 млн работников. 
РФ и подчеркнул, что оно допускает необоснованное вмешательство государства в работу профсоюзов, ограничение права на объединения и свободы деятельности общественных объединений, а также констатировал выявленные нарушения многих международных правовых актов, пактов о гражданских и политических правах, конвенций о защите прав человека и основных свобод, являющихся частью правовой системы РФ 1 . Данный процесс иллюстрирует не только способности и умение граждан сознательно отстаивать свои интересы, но и трудный, сложнейший по форме и содержанию поиск путей создания открытой конкурентной среды в специфической законотворческой и управленческой сфере.

Классовые противоречия обостряются, классовая борьба не исчезает. Тем не менее общественное устройство современной России, развитие демократических институтов, социальная мобильность позволяют во многом изменять природу социальных и политических конфликтов. И в этих условиях исследователи постмодернистских концепций считают, что было бы ошибочным вообще исключать классовую борьбу из арсенала современного анализа социальных отношений [Ильин 2003].

Процесс взаимодействия гражданина и правящего класса становится все более полицентричным, политика органов государственного управления антиномичной, выражающей в начале достижение прогресса, но итоговые результаты нередко свидетельствуют об изменениях в обратном направлении. Распространенность такого типа явлений становится укоренившейся реальностью.

Гражданин, государство и общество довольно часто оказываются в заложниках у правящего класса, структур государственного и муниципального управления. Счетная палата РФ в 2019 г. провела стратегический аудит 17 федеральных министерств, 7 служб и пришла к неутешительным выводам, констатируя: «...управление министерствами и ведомствами и оценка их эффективности не связаны с достижением национальных целей» 2 . В 2020 г. Счетная палата, проанализировав «итоговые эффекты» работы правительства РФ по обеспечению роста реальных доходов россиян и снижению бедности, обозначила вывод, что государственная политика не способна обеспечить достижение поставленных президентом целей; отдельного документа или комплекса мер в форме нацпроекта в сфере роста доходов и снижения бедности населения не существует ${ }^{3}$.

Сформулированные указом Президента РФ от 21 июля 2020 г. национальные цели - это предмет особого внимания граждан нашей страны. Люди стремятся активнее участвовать в осуществлении национальных целей, внести свой вклад в их реализацию, хотя отдельные целевые установки граждане по-прежнему не могут прояснить в полной мере. В частности, это относится к обоснованию критериев оценки достойного и эффективного труда, который подменяется мерками наемного труда не более как доходного занятия. Противоречивые и неопределенные представления граждан существуют и по вопросу создания комфортной среды для жизни.

Тайна многих невзгод коренится, по-видимому, в таком явлении, как тотальное отчуждение гражданина от результатов своего труда, от собственности не

1 Постановление Конституционного Суда РФ по делу «О проверке конституционного пункта 1 статьи 7 Ф3 “О профессиональных союзах, их правах и гарантиях” от 27.10.2020 №44-П.

2 Мериимская Е. Бесцельная власть. - Ведомости. 2020. 6 февр.

3 Кошкина А. Бедность - величина неизвестная. - Ведомости. 2020. 25 дек. 
только на средства производства, но и от собственности каждого на всеобщие, научно выработанные и применяемые условия труда. В современной России, как и в прошлом в советской системе, такая собственность у граждан не сформировалась. Тем не менее в ряде развитых стран государственные обязательства по этому поводу разрабатываются и реализуются. Причина подобных издержек и упущений чаще всего объясняется неосведомленностью граждан, но, быть может, и вторжением в сферу их личной свободы. Это требует более пристального изучения.

Политика в понимании многих чиновников - это такое ремесло, где отпирательство составляет стратегический метод. В одном случае можно выбрать измышления, дезинформацию, неточности, а в другом - суровую правду. Отпирательство представителей правящего класса есть самый простой выбор, позволяющий им продолжать жить в «удобном» мире.

Россия вновь жаждет перемен. По многолетним наблюдениям в прошлом отечественного известного ученого, социолога Питирима Сорокина, «мы уже давно думаем о социализме, но еще долго придется ждать его вещественного существования» [Сорокин 1992: 531]. Современные российские реалии свидетельствуют о сложном, многомерном, противоречивом поисковом характере взаимодействия гражданина и правящего класса, сущность которого состоит в приспособлении жизни к окружающей ее сфере бытия через эволюцию социальной и политической среды. К этому нужно прибавить еще и то условие, чтобы это взаимодействие было сознательным, а не инстинктивным или рефлекторным.

В такой ситуации все обоснованнее и острее ставится вопрос о доверии государства и общества. Впервые в нашей стране в новой редакции Конституции РФ изложено: «В Российской Федерации создаются условия для... взаимного доверия государства и общества» ${ }^{1}$. Это положение является фундаментальной основой формирования взаимодействия умов и взаимного целесообразного, рационального приспособления жизни и окружающей ее среды через эволюцию социальных и политических отношений. Доверие в общественных отношениях возникает на основе солидарности, единства коренных интересов. Для правящего класса движение в этом направлении требует доказательств высокой безупречности и оправданности каждого шага своей деятельности, создания системы и механизма обмена коллективным опытом с гражданами, который с каждым поколением меняется, но не исчезает. Наука по этому поводу не дает алгоритмических рецептов, но учит творить в горизонте того, как заметил президент РФ В.В. Путин, что гражданин, «гражданское общество будет играть ключевую роль в развитии России в будущем» 2 .

\section{Список литературы}

Арон Р. 1993. Демократия и тоталитаризм (пер. с франц.). М.: Текст. 303 с.

Ильин В.И. 2003. Классовая структура: классические концепции и современная Россия. - Отечественные записки. № 4. С. 492-506.

Ключевский В.О. 1990. Собрание в 9 томах. Т. 9. Материалы разных лет (под ред. В.Л. Янина). М.: Мысль. 525 с.

Литвак Б.Г. 2011. Наука управления: теория и политика. М.: Дело. 422 с.

Моска Г. 2006. Правящий класс. - Вся политика: хрестоматия (сост. В.Д. Нечаев, А.В. Филиппов). М.: Европа. С. 54-56.

\footnotetext{
${ }_{1}$ Конституция Российской Федерации (с гимном России), ст. 75.1. М.: Проспект. 2021.

2 Путин В.В. Выступление на итоговой сессии Международного клуба «Валдай» 22 октября 2020 г. - Российская газета. 2020. 23 окт.
} 
Поппер К.Р. 1992. Открытое общество и его враги (пер. с англ.). М.: Феникс; Международный фонд «Культурная инициатива». Т. 2. 528 с.

Сорокин П.А. 1992. Человек. Цивилизация. Общество (пер. с англ.; общ. ред., сост. и предисл. А.Ю. Согомонова). М.: Политиздат. 543 с.

Флорида Р. 2011. Креативный класс: люди, которые меняют будущее (пер. с англ.). М.: ИД «Классика -XXI». 432 с.

MIKHEEV Valentin Aleksandrovich, Dr.Sci. (Hist.), Academician of Russian Academy of Natural Sciences; Professor of the Russian Presidential Academy of National Economy and Public Administration (RANEPA) (82 Vernadskogo Ave, Moscow, Russia, 119571; mikheevva37@mail.ru)

\section{A CITIZEN AND THE RULING CLASS: WAYS OF INTERACTION IN MODERN RUSSIA}

Abstract. The article contains an analysis of the issues of the theory, means and methods of interaction between citizens and the ruling class in the context of the formation of the public authority system.

Keywords: citizen, ruling class, public authority, corruption, competition, confidence

ПАРМА Роман Васильевич - кандидат политических наук, доцент департамента политологии факультета социальных наук и массовых коммуникаций Финансового университета при Правительстве РФ (125993, Россия, г. Москва, Ленинградский пр-кт, 49, r.parma@таil.ru)

\section{ОПРЕДЕЛЕНИЯ И ПОДХОДЫ К ИССЛЕДОВАНИЮ ИЗБИРАТЕЛЬНЫХ ТЕХНОЛОГИЙ}

Аннотация. В статье сопоставляются различные трактовки избирательных технологий, которые рассматриваются как важнейшая составляющая арсенала политического управления обществом. Автор выделяет существующие ракурсы исследования политических технологий, среди которых функциональный, системный, структурно-функциональный, правовой (нормативный), психологический, маркетинговый, коммуникативный и сравнительно-исторический подходы. Дальнейшие перспективы исследований связаны с классификацией и развитием избирательных технологий в рамках обозначенных подходов.

Ключевые слова: политические технологии, избирательные технологии, выборы, исследовательские подходы, граждане, электорат

\section{Политические и избирательные технологии}

Понятие «технология» (от греч. «технэ»- искусство, мастерство и «логос» - слово, мысль) обычно подразумевает набор испытанных методов и инструментов производства, используемых для достижения желаемого результата или решения практической задачи. Технологии вне зависимости от области применения алгоритмизирует последовательность действий, поэтому могут применяться многократно, тиражироваться посредством передачи профессиональных умений и методик. В сфере политики, в центре которой находится 